\title{
Source Consultancy and Information Utilization Behavior among Ginger Growers
}

\author{
A.T. Krishnamurthy*, M. B. Ashoka, A.M. Maruthesh and G.B. Jagadeesh \\ University of Agricultural and horticultural Sciences \\ Shivamogga - 577225 (Karnataka) \\ *Corresponding author
}

\section{A B S T R A C T}

\begin{tabular}{|c|}
\hline Keywords \\
\hline $\begin{array}{l}\text { Information } \\
\text { utilization behavior, } \\
\text { Socio-economic } \\
\text { profile and } \\
\text { Suggestions }\end{array}$ \\
\hline Article Info \\
\hline $\begin{array}{l}\text { Accepted: } \\
22 \text { May } 2018 \\
\text { Available Online: } \\
\text { 10 June } 2018\end{array}$ \\
\hline
\end{tabular}

The present study was undertaken in selected villages of Mudigere taluk, Chikmaglur district of Karnataka during the year 2012, with 60 respondents, to know the socio-economic profile and Sources and information utilization behavior and suggestions offered by the ginger growing farmers for better yield. The data was collected from the respondents using structured interview schedule. The data collected was tabulated and analyzed using suitable statistical tool. The results of the study revealed that, majority of the respondents were middle aged with education up to primary to middle school having small sized family of 1 to 6 members with marginal land holdings and farming experience up to 5 years. With respect information utilization behavior, university scientists are the formal source contacted regularly by 40 per cent of the respondents. Fifty percent of them contacted officials of horticulture department occasionally followed by university scientists (46.66\%). The study also revealed that, in informal sources, 83.33 per cent of them contacted friends regularly followed by relatives $(68.33 \%)$. With respect to mass media, 46.66 per cent of them obtained information occasionally from television and publications. Research on development of soft rot resistant variety was the suggestion offered by the cent per cent respondents, followed by Technical support/ guidance by the universities $(95.00 \%)$ and Supply of good quality seed material at subsidized rate $(90.00 \%)$.

\section{Introduction}

Ginger is one of the earliest known oriental spices and is being cultivated in India for both as fresh vegetable and as a dried spice, since time immemorial. Ginger is obtained from the rhizomes of Zingiber officinale. The ginger family is a tropical group, especially abundant in Indo-Malaysian region, consisting of more than 1200 plant species in 53 genera.
The total production of ginger in the world is 1683.00 thousand tons with the total acreage of 310.43 thousand ha. China, India, Nepal and Thailand are the major producers of ginger in the world, having production of 396.60 thousand tons, 385.33 thousand tons, 210.79 thousand tons and 172.68 thousand tons respectively. India and Indonesia have the largest area under cultivation. The area under cultivation in India is 107.54 thousand ha and 
the total production of the country is 385.33 thousand tons.

India is a leading ginger producer in the world. More than $50 \%$ of total ginger production takes place in North East, Uttarakhand and Sikkim states. Most of ginger in North Eastern states is produced under organic conditions. Indian Institute of Spices Research, Kozhikode, Kerala and State Agricultural Universities identified / developed a number of superior and high yielding cultivars. Indian Spices Board established under the Ministry of Commerce, provides further support for expansion of area under spices, enhancing exports and provides technical guidance to the ginger growing farmers. Export of ginger increased from 8,332.91 tons in 2007-08 to 35,616.35 tons in 2011-12 in Quantum and increased from Rs 3,296.08 Lakh to Rs 26,626.77 Lakhs in value term. In Karnataka, the ginger is grown in an area of 49614 hectares with the production of 496556 metric tons.

Information seeking is a human process that requires adaptive and reflective control over the afferent and efferent actions of the information seeker (Murugan and Balasubramani, 2011). Advances in information communication technologies have revolutionized the information flow in agriculture field. Lot of information is available to farmers from various sources, but gathering of technical information from a credible sources play a vital role in bringing desirable changes among the farmers and also adoption of improved ginger cultivation practices. With this background, the study was undertaken with the following specific objectives,

\section{Objectives}

1 To know the socio-economic profile of ginger growing farmers
2 To find out the sources and extension information utilization behavior of ginger growing farmers

3 To enlist the suggestions offered by the ginger growing farmers for better yield

\section{Materials and Methods}

The study was undertaken in three villages Viz., Jannapura, Daradahalli and Banakal of Mudigere taluk, Chikmaglur district of Karnataka during the year 2013, to know the socio-economic profile, sources and information utilization behavior and suggestions offered by the ginger growing farmers for better yield. Based on the random sampling techniques 60 respondents at the rate of 20 ginger growing farmers from each village were selected. The data on personal and socio economic profile of respondents were categorized based on age (young, middle and old), education (illiterates, Primary and middle school- 1 to $7^{\text {th }}$ std., High school- 8 to $10^{\text {th }}$ std., PUC, Graduation and above), family size (small -1 to 6 members, medium -7 to 10 members, large -10 and above) and size of land holding (marginal farmers -below 2.5 acres, small farmers -2.5 to 5.0 acres and big farmers -above 5.0 acres), farming experiences (up to 5 years, 5 to 10 years, more than 10 years). Information seeking behavior of ginger growing farmers was categorized in to formal sources, informal sources and mass media. The data from the respondents were collected personally with help of well structured, pre tested interview schedule. The same were analyzed with the appropriate statistical tools and presented in below

\section{Results and Discussion}

Personal and Socio-economic profile of the respondents

It is clear from the table 1 that, majority $(70.00 \%)$ of the respondents belonged to 
middle aged category followed by old (20.00 $\%)$ and young $(10.00 \%)$ aged categories.

With respect to education, 56.66 per cent of them were educated up to primary to middle school. Respondents with education level up to high school were 21.66. Very less per cent of them were educated up to graduation. Remaining $i e, .8 .33$ and 3.33 per cent were educated up to PUC and illiterates, respectively.

With regard to family size, majority $(73.33 \%)$ of the respondents were having small families followed by medium (16.66\%) and large families $(10.00 \%)$, respectively.

Slightly more than half $(51.66 \%)$ of the respondents were marginal farmers followed by small $(35.00 \%)$ and big (13.33 \%) farmers categories.

With respect to farming experience, major chunks $(43.33 \%)$ of the respondents were having an experience up to 5 years. followed by 10 years $(36.66 \%)$ and 5 to 10 years $(20.00 \%)$

\section{Sources and extension information utilization behavior of ginger growers}

\section{Formal sources}

It is clear from the table 2 that, forty per cent of the respondents regularly gathered the information from university scientists, followed by spice board and horticulture department. University scientists are technically qualified and suggested remedy may be credible and provide solution immediately to their practical problems, this might be the reasons for majority of the farmers contacted university scientists for technical information.

Fifty per cent of the respondents contacted horticulture department occasionally followed by university scientists $(46.66 \%)$, spice board (30.00\%), NGOs $(30.00 \%)$ and farmers associations $(20.00 \%)$. Ginger is one of the important horticulture crop and horticulture department supply the critical inputs at subsidized rate and also provide technical guidance to the farmers. This might be the probable reasons for majority of the respondents contacting horticulture department occasionally for gathering information with regard to ginger cultivation.

Major chunk of the respondents never contacted agriculture department and farmers associations for information.

\section{Informal sources}

Majority $(83.33 \%)$ of the ginger growers gathered the information with related to ginger cultivation from their friends regularly followed by relatives $(68.33 \%)$ and progressive farmers (6.66 \%). Usually farmers are making friends with same age, education level, socio-economic status and likeminded, this may leads to develop a good relationship to understand each other to exchange their ideas, experiences, feelings and views among them before acceptance and adoption of technologies. This may be the probable reasons that, large number of respondents gathering information from their friends. These findings were in line with the earlier findings of Aziagba, and Okede (2011).

36.66 per cent of the respondents gathered the information occasionally from the progressive farmers.

Majority of them never contacted other informal sources like opinion leaders (86.66 $\%)$ and neighbors $(83.33 \%)$.

\section{Mass media}

Electronic media like television were regularly viewed by the 23.33 per cent of the 
respondents for gathering information followed by publications $(20.00 \%)$ and radio $(6.66 \%)$. Television is the one of the most effective electronic mass media through which participants can see and hear the message or information simultaneously and facilitate quick comprehension of the message by the participants.

Equal $(46.66 \%)$ per cent of the respondents occasionally obtained the information from television and publications followed by radio $(20.00 \%)$. Majority (74.37 \%) of the respondents never gathered information related to ginger cultivation from radio. Lack of leisure time and broadcasted time may not be suitable for the farmers and nowadays radios are gradually disappearing in rural areas this might be reasons for large number of respondents were never listen the radio. Similar results were obtained by Suresh Chandra Babu et al (2012).

Table 1 Personal and Socio-economic profile of the respondents

\begin{tabular}{|c|c|c|c|}
\hline SI. No. & Characteristics & Number & Percentage \\
\hline \multirow[t]{4}{*}{1} & \multicolumn{3}{|l|}{ Age } \\
\hline & Young (<35 years) & 6 & 10.00 \\
\hline & Middle ( $36-50$ years) & 42 & 70.00 \\
\hline & Old (>50 years $)$ & 12 & 20.00 \\
\hline \multirow[t]{6}{*}{2} & \multicolumn{3}{|l|}{ Education } \\
\hline & Illiterates & 2 & 3.33 \\
\hline & Primary and middle school ( 1 to $\left.7^{\text {th }}\right)$ & 34 & 56.66 \\
\hline & High school $\left(8\right.$ to $\left.10^{\text {th }}\right)$ & 13 & 21.66 \\
\hline & PUC & 5 & 8.33 \\
\hline & Graduation & 6 & 10.00 \\
\hline \multirow[t]{4}{*}{3} & \multicolumn{3}{|l|}{ Family size } \\
\hline & Small (1 to 6 members) & 44 & 73.33 \\
\hline & Medium (7 to 10members) & 10 & 16.66 \\
\hline & Large (10 and above) & 6 & 10.00 \\
\hline \multirow[t]{4}{*}{4} & \multicolumn{3}{|l|}{ Land holding } \\
\hline & Small farmers ( 2.5 to 5.0 acres) & 21 & 35.00 \\
\hline & Big farmers $(>5.0$ acres $)$ & 8 & 13.33 \\
\hline & Marginal farmers $(<2.5$ acres $)$ & 31 & 51.66 \\
\hline \multirow[t]{4}{*}{5} & Farming experiences & & \\
\hline & Up to 5 years & 26 & 43.33 \\
\hline & 5 to 10 years & 12 & 20.00 \\
\hline & More than 10 years & 22 & 36.66 \\
\hline
\end{tabular}


Table.2 Distribution of respondents according to their sources and information utilization behavior

\begin{tabular}{|c|c|c|c|c|c|c|c|}
\hline \multirow{2}{*}{$\begin{array}{l}\text { Sl. } \\
\text { No. }\end{array}$} & \multirow[t]{2}{*}{ Information source } & \multicolumn{2}{|c|}{ Always } & \multicolumn{2}{|c|}{ Occasionally } & \multicolumn{2}{|c|}{ Never } \\
\hline & & $\mathbf{F}$ & $\%$ & $\mathbf{F}$ & $\%$ & $\mathbf{F}$ & $\%$ \\
\hline \multirow[t]{7}{*}{1} & \multicolumn{7}{|l|}{ Formal sources } \\
\hline & Agriculture department & - & - & - & - & 60 & 100.00 \\
\hline & Horticulture department & 8 & 13.33 & 30 & 50.00 & 22 & 36.66 \\
\hline & University scientists & 24 & 40.00 & 28 & 46.66 & 8 & 13.33 \\
\hline & Spice board & 12 & 20.00 & 18 & 30.00 & 30 & 50.00 \\
\hline & NGOs & - & - & 18 & 30.00 & 42 & 70.00 \\
\hline & Farmer association & - & - & 12 & 20.00 & 48 & 80.00 \\
\hline \multirow[t]{6}{*}{2} & \multicolumn{7}{|l|}{ Informal sources } \\
\hline & Friends & 50 & 83.33 & 8 & 13.33 & 2 & 3.33 \\
\hline & Relatives & 41 & 68.33 & 8 & 13.33 & 11 & 18.33 \\
\hline & Neighbors & - & - & 10 & 16.66 & 50 & 83.33 \\
\hline & Progressive farmers & 4 & 6.66 & 22 & 36.66 & 34 & 56.66 \\
\hline & Opinion leaders & - & - & 8 & 13.33 & 52 & 86.66 \\
\hline \multirow[t]{4}{*}{3} & \multicolumn{7}{|l|}{ Mass media } \\
\hline & Television & 14 & 23.33 & 28 & 46.66 & 18 & 30.00 \\
\hline & Radio & 4 & 6.66 & 12 & 20.00 & 44 & 74.37 \\
\hline & Publications & 12 & 20.00 & 28 & 46.66 & 20 & 33.33 \\
\hline
\end{tabular}

Table.3 Suggestions offered by the ginger growing farmers for better yield

\begin{tabular}{|c|c|c|c|}
\hline $\begin{array}{l}\text { Sl. } \\
\text { No. }\end{array}$ & Suggestions & Frequency & Percentage \\
\hline 1 & Supply of good quality seed material at subsidized rate & 54 & 90.00 \\
\hline 2 & Research on development of soft rot resistant variety & 60 & 100.00 \\
\hline 3 & Establishment of good market facilities & 48 & 80.00 \\
\hline 4 & $\begin{array}{l}\text { Technical support/ guidance by the universities and } \\
\text { developmental departments by time to time }\end{array}$ & 57 & 95.00 \\
\hline 5 & Formations of commodity groups/growers associations & 34 & 56.66 \\
\hline
\end{tabular}

Suggestions offered by the ginger growing farmers for better yield

Research on development of soft rot resistant variety was the major suggestion offered by the cent per cent of the ginger growing farmers. Other important suggestions offered were, technical support/ guidance by the universities and developmental departments by time to time $(95.00 \%)$, supply of good quality seed material at subsidized rate $(90.00$ 
$\%$ ), establishment of good market facilities $(80.00 \%)$, and formation of commodity groups/growers associations (56.66\%). Soft rot disease one of the major disease which leads drastically reduces the yield which in turn causes the huge economic losses to the farmers.

It could be concluded from the results that, majority of the respondents belonged to middle aged and educated up to primary and middle school with small family, marginal holding and having five years farming experiences. Study also reveals that, the ginger growing farmers regularly gathered the information with related to ginger cultivation from their friends followed by university scientists and television, further, they suggested to develop a variety resistant to soft rot and provide technical guidance by the universities and developmental departments persistently.

\section{Recommendations}

State agricultural universities have to undertake research to develop a soft rot resistant varieties

Institutions involved in the extension activities have to take necessary measures to organize demand driven extension activities to enhance the knowledge and skill in order to manage their crop enterprise
Administrators and policy makers have to initiate necessary action to formation of commodity interest groups and distribution of quality seed materials at subsidized rate.

Government make a necessary efforts to establish a separate regulated market to get good price for their produce

\section{References}

Aziagba, P. C. and Okede, G. W. (2011). Information seeking behaviour of cassava farmers in upata clan, Ekpeye community of rivers state, Nigeria. $J$ Res. Edu. \& Soc., 2(3): 1-7.

Gurav.K.V. and Jagadale.U.D. (2013). A study on personal profile and information sources used by the farmers in production of organic jiggery. Agric. Update, 8 (1\&2): 19-21.

.Sendilkumar. R. (2010). Knowledge and information sources utilisation pattern of soybean growers. Indian Res. J. Ext. Edu., 10 (3): 71-74

Suresh Chandra Babu, Claire J., Glendenning, Kwadwo Asenso-Okyere and Senthil Kumar Govindarajan. (2012). Farmers' information needs and search behaviors - Case Study in Tamil Nadu, India. IFPRI Discussion Paper 01165. Washington, DC: International Food Policy Research Institute.

\section{How to cite this article:}

Krishnamurthy, A.T., M.B. Ashoka, A.M. Maruthesh and Jagadeesh, G.B. 2018. Source Consultancy and Information Utilization Behavior among Ginger Growers. Int.J.Curr.Microbiol.App.Sci. 7(06): 3305-3310. doi: https://doi.org/10.20546/ijcmas.2018.706.387 